\title{
The protection against discrimination based on sexual orientation under the African human rights system
}

\author{
Annika Rudman* \\ Associate Professor, Department of Public Law, Faculty of Law, University of \\ Stellenbosch, South Africa
}

\begin{abstract}
Summary
Recent legislation proposed or passed in Nigeria, Uganda and The Gambia has put the spotlight on the plights of homosexual persons living in sub-Saharan Africa. In Nigeria, discriminatory laws prohibit same-sex marriages and ban gay clubs and organisations. In Uganda, the Prohibition of the Promotion of Unnatural Sexual Practices Bill of 2014, with contents similar to the notorious Anti-Homosexuality Act, is being considered after a ruling by the Ugandan Constitutional Court rendering the Anti-Homosexuality Act unconstitutional. In The Gambia, the Penal Code has been amended recently to add the crime of 'aggravated homosexuality' with a lifetime prison sentence for any person found guilty. The rights to dignity and equality are protected under the African Charter on Human and Peoples' Rights; however, competing local and global values are arguably growing in Africa, challenging this right. This article explores two main problems: first, how the rights to dignity, equality and non-discrimination should generally be interpreted and applied under the regional African human rights system when related to sexual orientation. In this regard I draw on the interpretation of these rights under international human rights law as well as the jurisprudence of the European Court of Human Rights and its Inter-American counterpart. Second, it analyses the procedural or other hurdles that may stand in the way of brining a claim of discrimination based on sexual orientation to the African Commission on Human and Peoples' Rights or the African Court on Human and Peoples' Rights. In this regard, I specifically consider the general restrictions placed on individuals and NGOs in bringing
\end{abstract}

* $\quad$ LLB LLM (Lund), PhD (Gothenburg); arudman@sun.ac.za 
complaints to the Court and the real potential of the Commission to act as a conduit to the Court in cases involving rights related to sexual orientation, bearing in mind its inconsistent approach to same-sex sexuality. The article addresses these questions by analysing some key developments by the Inter-American Commission on Human Rights and the Inter-American Court of Human Rights. The main objective is to utilise the approach of these institutions to explore both the legal avenues under the Protocol to the African Charter on Human and Peoples' Rights on the Establishment of an African Court on Human and Peoples' Rights and the rights and obligations under the African Charter available to anyone who would want to challenge any domestic law criminalising same-sex consensual sexual acts and/or any of the other related prohibitions.

Key words: Equality; dignity; sexual orientation; gay and lesbian rights; African Charter on Human and Peoples' Rights

\section{Introduction}

Recent legislation proposed or passed in Nigeria ${ }^{1}, \mathrm{Uganda}^{2}$ and The Gambia $^{3}$ has again put the spotlight on the plight of homosexual persons living in sub-Saharan Africa. In these specific countries, as former British colonies, both male and female consensual same-sex sexual acts were already criminalised ${ }^{4}$ through the relevant Penal Codes, ${ }^{5}$ criminalising acts where 'anyone has carnal knowledge of any person against the order of nature' and through the criminalisation of 'indecent' or 'gross indecent' practices. However, further legislation or amendments to existing legislation have been introduced, building on these particular crimes to, on the one hand, further emphasise and

1 Same-Sex Marriage (Prohibition) Act 2013, NASS/CAN/115/VOL 31/24, 30 December 2013, promulgated on 13 January 2014.

2 Anti-Homosexuality Act 2014 and the Prohibition of the Promotion of Unnatural Sexual Practices Bill of 2014.

3 The Gambia Criminal Code (Amendment) Act, 25 August 2014. Supplement ' $C$ ' to The Gambia Gazette 15 of 16 October 2014. The Amendment adds sec 144A 'Aggravated homosexuality'.

4 As pointed out in the 2008 Report by Human Rights Watch (HRW) 'This alien legacy - The origins of "sodomy" laws in British colonialism' http://www.hrw.org/ reports/2008/12/17/alien-legacy-0 (accessed 2 April 2015), these codes do not criminalise 'homosexuality' per se, but refer to intercourse against the order of nature and indecency, as has been interpreted differently in different legal contexts. In the latest report by the International Lesbian Gay Bisexual Trans and Intersex Association (ILGA), May 2014 http://www.old.ilga.org/Statehomophobia/ ILGA_SSHR_2014_Eng.pdf (accessed 13 February 2015), it characterises male and female same-sex consensual sexual acts as illegal.

5 Nigeria: Criminal Code Act, ch 77, Laws of the Federation of Nigeria 1990, ch 21: Offences against Morality, secs 214, $215 \& 217$. With regard to the crime of 'gross indecency' as stipulated in sec 217, it refers only to 'any male person'. Uganda: ch 120 of the Penal Code Act 1950, ch 14, Offences against Morality, secs 145,146 \& 148. Before the Penal Code Amendment (Gender References) Act 2000 was enacted, only same-sex acts between men were criminalised. In 2000, that Act 
put harsher penalties on the crime of 'homosexuality' ${ }^{6}$ and, on the other, widen the scope of the law to reach other, arguably related, areas such as same-sex marriage, advocacy and social life.

In January 2014, the Nigerian President promulgated the Same-Sex Marriage (Prohibition) Act 2013 (SSMA). The SSMA outlaws ${ }^{7}$ samesex marriages and prescribes ten years' imprisonment for anyone who formalises or witnesses a same-sex marriage. It furthermore bans gay organisations and clubs in Nigeria. ${ }^{8}$ In April 2014, a Nigerian citizen living abroad challenged the validity of the SSMA. ${ }^{9}$ The Federal High Court in Abuja was asked to declare the sections referring to the prohibition and invalidity of same-sex marriages invalid. The petitioner claimed that the SSMA violated fundamental rights of Nigerian citizens protected under the Nigerian Constitution, ${ }^{10}$ as well as under the relevant articles of the African Charter on Human and Peoples' Rights (African Charter). The Federal High Court dismissed the case on the ground that the complainant lacked the required locus standi to present the claim on behalf of other Nigerians because he, himself, had not suffered from the action of the Federal State under the Act. ${ }^{11^{\prime}}$

Similarly, in early 2014 the Ugandan President signed the AntiHomosexuality Bill ${ }^{12}$ into law, promulgating the Anti-Homosexuality Act 2014 (AHA). A few months later, the Constitutional Court of Uganda struck down the AHA based on the lack of a quorum ${ }^{13}$ in

was passed and changed references to 'any male' to 'any person', so that grosslyindecent acts between women were criminalised as well, and are now punishable by up to seven years' imprisonment. The Gambia: Criminal Code of 1965 as amended in 2005 and 2014, secs 144(1\& 2) and 144A (see n 3 above and 20 below). The amendment done to the Penal Code in 2005, The Gambia Gazette 2 August 2005 , criminalised lesbian practices by substituting for the words 'a male' with 'any' and by adding subsec (2) that reads: 'In this section "carnal knowledge of any person against the order of nature" includes (a) carnal knowledge of the person through the anus or the mouth of the person; (b) inserting any object or thing into the vulva or the anus of the person for the purpose of simulating sex; and (c) committing any other homosexual act with the person.'

$6 \quad$ Human Rights Watch (n 4 above) 4.

7 Sec 5(1) of the SSMA states that '[a] person who enters into a same-sex marriage contract or civil union commits an offence and is liable on conviction to a term of 14 years' imprisonment'.

8 Sec 5(2) of the SSMA states that ' $[a]$ person who registers, operates or participates in gay clubs, societies and organisation, or directly or indirectly makes public show of same-sex amorous relationship in Nigeria commits an offence and is liable on conviction to a term of 10 years' imprisonment'.

9 Mr Teriah Joseph Ebah v Federal Government of Nigeria Suit FHC/ABJ/CS/197/2014.

10 Of 1999.

11 Ebah (n 9 above).

12 The Anti-Homosexuality Bill 18 of 2009, Bills supplement to the Uganda Gazette 47, Vol CII (25 September 2009).

$13 \mathrm{Sec} 88$ of the Ugandan Constitution of 1995 prescribes that the quorum of parliament shall be one-third of all members of parliament entitled to vote. 
parliament when the Bill was passed. ${ }^{14}$ As in the Nigerian challenge, the Court did not hear any substantial arguments as presented by the petitioners. ${ }^{15}$ Nonetheless, a new Bill with similar contents is being drafted. Only three months after the ruling of the Ugandan Constitutional Court, the first draft of the Prohibition of the Promotion of Unnatural Sexual Practices Bill of 2014 (Sexual Practices Bill) was presented to a number of parliamentarians and leaked to the media. ${ }^{16}$ The proposed Sexual Practises Bill does not refer to same-sex sexual acts as such, but to the 'performance of unnatural sexual practices' which is linked to the Ugandan Penal Code ${ }^{17}$ and the listed offences against morality. It casts a wide net in defining the acts criminalised in section 145 of the Penal Code as sexual acts 'between persons of the same sex, or with or between transsexual persons, a sexual act with an animal, and anal $\operatorname{sex}^{\prime}{ }^{18}$ These crimes are punishable with imprisonment for life. Comparably to the AHA, the Sexual Practices Bill criminalises the promotion, funding, exhibiting and inducement as related to the crime of unnatural sexual practices. Section 2(h) criminalises the act of solemnisation of a same-sex marriage. Any person who attempts or solemnises a same-sex marriage is liable upon conviction to up to seven years' imprisonment. The Sexual Practices Bill furthermore disqualifies consent as a defence against any of the crimes listed and removes all parental rights from any person convicted under the proposed Act. ${ }^{19}$

In The Gambia, the Penal Code has recently been amended to add the crime of 'aggravated homosexuality' with a lifetime prison sentence for any person found guilty under any of the prerequisites. ${ }^{20}$ In The Gambia, consensual male and female same-sex sexual acts ${ }^{21}$

14 The Court found that the Act of the 9th Parliament in enacting the AntiHomosexuality Act 2014 on 20 December 2013 without quorum in the House is inconsistent with and in contravention of arts 2(1) and (2) and 88 of the Constitution of the Republic of Uganda 1995 and Rule 23 of the Parliamentary Rules of Procedure and thus null and void. Oloka-Onyango \& 9 Others $v$ AttorneyGeneral (2014) UGCC 1420.

15 Oloka-Onyango (n 14 above) 22.

16 Human Rights Campaign 'Uganda parliament introduces dangerous anti-LGBT legislation again' http://www.hrc.org/blog/entry/uganda-parliament-introducesdangerous-anti-lgbt-legislation-again (accessed 1 April 2015).

17 n 5 above.

18 The Prohibition of the Promotion of Unnatural Sexual Practices Bill of 2014, sec 1, Interpretation.

19 n 18 above, secs $7 \& 8$.

20 Sec 144A: 'A person commits this offence if he or she engages in a homosexual act and the (a) person against whom the offence is committed is below the age of eighteen; (b) offender is a person living with HIV/AIDS; (c) offender is a parent or guardian of the person against whom the offence is committed; (d) offender is a person in authority over the person against whom the offence is committed; (e) victim of the offence is a person with disability; $(f)$ offender is a serial offender; or (g) offender applies, administers or causes to be administered by any man or woman, any drug, matter or substance with intent to stupefy or overpower him or her, so as to enable any person to have unlawful carnal connection with any person of the same sex.'

21 n 5 above. 
were already criminalised under the existing amended Penal Code. However, the new amendment widened the scope of the criminalisation and increased the sentence prescribed.

These developments do not only re-enforce the existing criminalisation of consensual same-sex conduct in all its forms, but it forces homosexual persons of all ages to live in absolute fear of harassment, torture, extortion, mob violence and denunciation. ${ }^{22}$ Arguably, these laws and the proposed Bill effectively deprive homosexual persons of their dignity and most basic human rights, rendering them utterly vulnerable and, in some cases, effectively disenfranchised. In this article I use the Nigerian SSMA and the approach by the Ugandan government towards same-sex sexuality in the AHA and the Sexual Practices Bill (discriminatory laws) ${ }^{23}$ purely as examples. The discussion is, however, equally relevant to the situation of homosexual persons in The Gambia or any of the other $34^{24}$ African countries where consensual same-sex conduct is criminalised. ${ }^{25}$ It is important at the outset to clarify that I in this article focus exclusively on male and female consensual same-sex sexual acts and their implications for homosexual persons. In this regard, I will be heavily biased towards the discussion about sexual orientation as a suspect ground and very little attention will be given to the equally important protection relating to gender identity.

More than 60 years ago, Arendt wrote: ${ }^{26}$

Something much more fundamental than freedom and justice, which are rights of citizens, is at stake when belonging to a community into which one is born is no longer a matter of course and not belonging no longer a matter of choice ... This extremity, and nothing else, is the situation of people deprived of human rights. We become aware of the existence of a right to have rights ... and a right to belong to some kind of organized community, only when millions of people emerge who had lost and could not regain these rights because of the new global political situation.

Arendt made these observations in the context of the vast number of stateless refuges produced by World War II. However, today Arendt's theoretical framework well frames the marginalisation, violence, discrimination and loss of dignity experienced by many homosexual

22 R Thoreson \& S Cook (eds) IGLHRC Report 'Nowhere to turn: Blackmail and extortion of LGBT people in sub-Saharan Africa' (2011) 6; Human Rights Watch (n 4 above) 3-4.

23 The reference to 'discriminatory laws' in this article is made with the understanding that there is at the time of writing this article no law of this nature in force in Uganda.

24 Algeria, Angola, Botswana, Burundi, Cameroon, Central African Republic, Comoros, Egypt, Eritrea, Ethiopia, Ghana, Guinea, Kenya, Lesotho, Liberia, Libya, Malawi, Mauritania, Mauritius, Morocco, Mozambique, Namibia, Senegal, Seychelles, Sierra Leone, Somalia, South Sudan, Sudan, Swaziland, Tanzania, Togo, Tunisia, Zambia and Zimbabwe. See LP Itaborahy \& I Zhu 'State-sponsored homophobia - A world survey of laws: Criminalisation, protection and recognition of same-sex love' ILGA Report (n 4 above) 18.

25 As above.

26 H Arendt The origins of totalitarianism (1951) 293-294. 
persons living in sub-Saharan Africa. ${ }^{27}$ The right to dignity, which embraces all fundamental human rights, is a prerequisite to the right to have rights, as expressed by Arendt. Ackermann explains that human dignity should be understood as both 'the capacity for and the right to respect as a human being' ${ }^{28}$ He describes human dignity as enabling human beings to have self-awareness and a sense of selfworth, to exercise self-determination, to develop their personalities and to strive for self-fulfilment. He furthermore importantly acknowledges that dignity 'arises from the capacity of human beings to enter into meaningful relationships with others' ${ }^{29}$ If a person is prevented from accessing the rights to free speech, association and assembly, if he or she cannot marry, if a person's expression of his or her innermost emotions is subject to lifetime imprisonment or the death penalty, that person has no dignity. Archbishop Desmond Tutu framed this argument well when he equated the discrimination against gay people in Uganda with the horrors of Nazi Germany and the apartheid era in South Africa. ${ }^{30}$

\section{Scope}

I set out to explore two main problems in this article. Firstly: How should the rights to dignity, equality and non-discrimination be interpreted and applied under the regional African human rights system when related to sexual orientation? In this regard, I draw on the interpretation of these rights under international human rights law as well as the jurisprudence of the European Court of Human Rights (European Court) and its Inter-American counterpart. I specifically put emphasis on a recent case from the Inter-American Court of Human Rights (Inter-American Court), Atala and Daughters v Chile ${ }^{31}$ (Atala case) to point to similarities between the laws. I use this perspective as I explore non-discrimination and potential human rights violations under the African Charter related to the criminalisation of same-sex consensual sexual acts.

27 See 'From torment to tyranny enhanced persecution in Uganda following the passage of the Anti-Homosexuality Act 2014' 20 December 2013-1 May 2014 2-4, http://www.sexualminoritiesuganda.com/Torment\%20to\%20Tyranny\%200905-2014\%20FINAL. pdf (accessed 27 March 2015); 'Realities and rights of gender non-conforming people and people who engage in same-sex sexual relations in Africa - A civil society report' http://www.cal.org.za/new/?page_id=1490 (accessed 27 March 2015); 'Violence based on perceived or real sexual orientation and gender identity In Africa' 2013 http://www.cal.org.za/new/?page_id=1490 (accessed 25 March 2015).

28 L Ackermann Human dignity: Lodestar for equality in South Africa (2013) 86.

29 As above.

30 'Desmond Tutu condemns Uganda's proposed new anti-gay law' The Guardian 23 February 2014 http://www.theguardian.com/world/2014/feb/23/desmondtutu-condemns-uganda-proposed-anti-gay-law (accessed 14 February 2015).

31 Karen Atala and Daughters v Chile IACHR (23 July 2008) Ser L/Doc 22 Rev 1. 
Secondly: What procedural or other hurdles may stand in the way of bringing a claim of discrimination based on sexual orientation to the African Commission on Human and Peoples' Rights (African Commission) or the African Court on Human and Peoples' Rights (African Court)? In this regard, I specifically consider the general restrictions placed on individuals and non-governmental organisations (NGOs) in bringing complaints to the African Court and the real potential of the African Commission to act as a conduit to the Court in cases involving rights related to sexual orientation, bearing in mind its inconsistent approach to same-sex sexuality. I address these questions by analysing some key developments by the Inter-American Commission on Human Rights (Inter-American Commission) and the Inter-American Court. The main objective is to utilise the approach of these institutions to explore both the legal avenues under the Protocol to the African Charter on Human and Peoples' Rights on the Establishment of an African Court on Human and Peoples' Rights (African Court Protocol) and the rights and obligations (as mentioned above) under the African Charter ${ }^{32}$ available to anyone who would want to challenge any domestic law criminalising same-sex consensual sexual acts or any of the other related prohibitions as set out in the legislation enunciated above. I use the jurisprudence of the Inter-American system as an example, firstly because the level of development and the importance of culture and tradition are easier compared (not similar) than in the European context (as is further elaborated on in section 5); and, secondly, because of the similar positioning and powers of the Inter-American Commission and the African Commission.

As a point of departure, it is important to note that the African Commission has to some extent already reacted to questions regarding sexual orientation as a ground for non-discrimination. It has, however, only been faced with one single complaint where this issue was at the centre of the complaint. In 1994, a communication ${ }^{33}$ reached the African Commission asking the Commission to consider the legal status of homosexuals in Zimbabwe. According to the complainant, the prohibition of sexual contacts between consenting adult homosexual men in private was enforced in Zimbabwe, and it was furthermore encouraged by statements against homosexuals by the President and by the then Minister of Home Affairs. The compliant was, however, withdrawn by the applicant. ${ }^{34}$

32 This also includes the relevant articles of the African Women's Protocol and the African Children's Charter as further discussed in subsec 4.

33 Courson v Zimbabwe (2000) AHRLR 335 (ACHPR 1995).

34 The commissioner acting as the rapporteur in this case has been quoted as stating the following: '[B]ecause of the deleterious nature of homosexuality, the Commission seizes the opportunity to make a pronouncement on it. Although homosexuality and lesbianism are gaining recognition in certain parts of the world, this is not the case in Africa. Homosexuality offends the African sense of 
In 2006, the African Commission handed down its findings in Zimbabwe Human Rights NGO Forum v Zimbabwe. ${ }^{35}$ In this decision, the Commission confirmed that article 2 of the African Charter safeguards 'equality of treatment for individuals irrespective of ... sexual orientation' ${ }^{36}$ This opinion by the Commission was, however, expressed obiter, as the case did not concern the issue of sexual orientation as such.

The African Commission has furthermore related to issues of sexual orientation as part of the Commission's mandate to grant observer status (which is addressed further in section 5.3) and as part of its promotional mandate by posing questions and expressing its concerns through the state reporting mechanism and the Special Rapporteurship. ${ }^{37}$ As neither the African Commission nor the African Court has formally acted on a direct or indirect complaint by an individual or NGO, I argue that the issue of the status of sexual orientation under the African Charter is far from settled. Therefore, an analysis of the nature, suggested above, has the potential of revealing how dignity, non-discrimination and equality, as recalled in articles 2 and 3 of the African Charter, articles 1, 2 and 8 of the Protocol to the African Charter on the Rights of Women in Africa (African Women's Protocol) and article 3 of the African Charter on the Rights and Welfare of the Child (African Children's Charter) should be understood under the regional African human rights system.

In grappling with the problems set out above, I have elected to engage with the understanding of non-discrimination from the perspective of the universality of human rights, more appropriately, the universal application of the rights to equality and dignity. In this regard, the relevance of the development of human rights related to sexual orientation internationally and in other regional contexts becomes paramount in the interpretation of the rights set out in the African Charter, the African Women's Protocol and the African Children's Charter. In this regard, Huber's thoughts on universality puts Arendt's framework, as discussed above, in context in indicating that 'cosmopolitanism takes seriously that everybody matters equally and that human persons have a right to have rights' ${ }^{38}$ In line with Huber's argument, a broad-based society, a society that aims to be

dignity and morality and is inconsistent with positive African values.' EA Ankumah The African Commission on Human and Peoples' Rights: Practice and procedures (1996) 174, as quoted in F Viljoen International human rights law in Africa (2012) 265.

35 (2006) AHRLR 128 (ACHPR 2006).

36 Zimbabwe Human Rights NGO Forum (n 35 above) para 169.

37 See R Murray \& F Viljoen 'Towards non-discrimination on the basis of sexual orientation: The normative basis and procedural possibilities before the African Commission on Human and Peoples' Rights and the African Union' (2007) 29 Human Rights Quarterly 102-104; Viljoen (n 34 above) 266.

38 W Huber 'Human rights and globalisation' STIAS lecture (17 February 2013) University of Stellenbosch Faculty of Law (transcript of the lecture on file with the author). 
part of the international community, would arguably accept the developments towards inclusion and away from exclusion in line with the idea of the universal approach to human rights. However, it is clear from the reactions of the governments in, for example, Uganda and Nigeria that they do not accept the approach to human rights related to sexual orientation as developed, through soft law, by the international community and in other regional human rights systems, such as the European and Inter-American systems. In this regard, borrowing from Huber again, it appears that exceptionalism as one expression of human rights scepticism is finding an ever-more fertile ground amongst African states and its citizens. The idea that we are, as expressed in the Universal Declaration of Human Rights (Universal Declaration), '[a]ll human beings ... born free and equal in dignity and rights' appears to be a rule with many exceptions if viewed from the perspective of homosexual persons' right to dignity and equality in sub-Saharan Africa, thus making it even more important to analyse the protection against discrimination based on sexual orientation under the African human rights system

\section{International and European legal backdrops}

As part of the analysis of the first problem set out in the preceding section, I attempt to contextualise, in a brief manner, these rights by looking to international human rights law and the substantive case law of the European Court related to sexual orientation. There is no international legally-binding instrument that specifically lists sexual orientation as a suspect ground. In addition, customary international law cannot be viewed as having developed to a point where it includes discrimination based on sexual orientation, as it has vis-à-vis discrimination based on, for example, race. ${ }^{39}$ State practice is too diverse for a customary norm of this nature to have developed and open expressions of objections to such norms are noticeable. This is particularly visible in the opinions expressed at various United Nations (UN) human rights bodies, such as the UN Human Rights Council (UNHRC). The UNHRC clearly remains divided on the issue of sexual orientation as a suspect ground. ${ }^{40}$ To find support for the inclusion of sexual orientation under the non-discrimination clauses in existing international human rights law, we have to look to soft law. Soft law does not have legally-binding force, but can help us recognise the

39 A Cassese International law (2005) 203.

40 See as an example the voting records of the Human Rights Council with regard to the two resolutions on Human Rights, Sexual Orientation and Gender Identity, the UN Human Rights Council's Resolution on Human Rights, Sexual Orientation and Gender Identity UN Doc A/HRC17/L.9/Rev 1, (Human Rights Council 15 June 2011) and the UN Human Rights Council's Resolution on Human Rights, Sexual Orientation and Gender Identity A/HRC/27/L.27/Rev 1, (26 September 2014). With regard to the 2011 Resolution, only two of the 13 African states (Libya suspended) on the Human Rights Council (South Africa as the sponsor and Mauritius) voted in favour of the Resolution. Nigeria and Uganda voted against, 
reach of obligations already in force. Soft law can also direct the future development of customary international law. Considerable soft law has been produced within the UN structure; arguably enough to justify the classification of sexual orientation as a suspect ground. ${ }^{41}$ Important to this discussion is the decision of the UN Human Rights Committee in Toonen $v$ Australia 42 In Toonen, the Committee concluded that "reference to "sex" in articles 2, paragraph 1 and 26 [of the ICCPR] is to be taken as including sexual orientation'. ${ }^{43}$ Decisions of this nature, within the context of the International Covenant on Civil and Political Rights (ICCPR) with its 168 state parties, including all African states except South Sudan, are valuable as soft law and as an important step towards the development of customary international law.

On the regional level, the European Court, in applying the European Convention on Human Rights and Fundamental Freedoms (European Convention), has made very important contributions to the understanding of the protection of rights related to sexual orientation under the European Convention. In this regard, the European Court has covered a number of different topics that are relevant to the protection of a wide array of what can best be referred to as lesbian, gay, bisexual and transgender (LGBT) ${ }^{44}$ rights. The European Court has moved from applying the right to privacy in Dungeon $v U K^{45}$ and

http://www.ohchr.org/EN/NewsEvents/Pages/DisplayNews.aspx?NewsID=11167 \&LangID=E (accessed 27 March 2015). With regard to the 2014 Resolution, only one of the 11 African states on the Human Rights Council (South Africa) voted in favour of the Resolution http://www.ohchr.org/en/NewsEvents/Pages/Display News.aspx?NewsID=15109\&LangID=E (accessed 27 March 2015).

41 The Yogyakarta Principles on the Application of International Human Rights Law in relation to Sexual Orientation and Gender Identity, http://www.yogyakarta principles.org/principles_en.htm (accessed 1 April 2015); UN Declaration on Human Rights and Sexual Orientation http://www.ohchr.org/EN/NewsEvents/ Pages/DisplayNews.aspx?NewsID=11167\&LangID=En and Gender Identity, UN Doc A/63/635 (UNGA 22 December 2008); the UN Human Rights Council's Resolution on Human Rights, Sexual Orientation and Gender Identity 2011 (n 40 above); Report on discriminatory laws and practices and acts of violence against individuals based on their sexual orientation and gender identity by the United Nations High Commissioner for Human Rights (UNHCHR), UN Doc A/HRC/19/41 (UNHCHR 17 November 2011); the UN Human Rights Council's Resolution on Human Rights, Sexual Orientation and Gender Identity 2014 (n 40 above); the Report of the United Nations Special Rapporteur on the right to education, UN Doc. A/65/162, 23 (23 July 2010); General Comment 20 UN Doc E/C.12/GC/20, 32 (ESCR Committee 2 July 2009), General comment 13 UN Doc CRC/C/GC/13, 60 and 72(g) (Committee on the Rights of the Child 18 April 2011); General Comment 2 UN Doc CAT/C/GC/2, 21 (Committee against Torture 24 January 2008); General Recommendation 28 UN Doc CEDAW/C/GC/28 18 (Committee on the Elimination of Discrimination against Women 16 December 2010).

42 Communication 488/1992, UN Doc CCPR/C/50/D/488/1992 (1994).

43 Toonen ( $\mathrm{n} 42$ above) para 8.7.

44 This acronym is used in its widest sense as presented by the IACHR Rapporteurship on the Rights of LGBT Persons. For further information, refer to 'Relevant concepts and applicable terminology' https://www.oas.org/en/iachr/lgtbi/mandate/con cepts.asp (accessed 13 February 2015).

45 Dudgeon v United Kingdom ECHR (23 September 1981) Ser A 45. 
a number of subsequent cases, ${ }^{46}$ to strike down anti-sodomy laws in Europe and onto the judgment in Salgueiro da Silva Motua $v$ Portugal, ${ }^{47}$ where the European Court argued that sexual orientation was a distinction prohibited by article 14 of the European Convention. It has furthermore dealt with LGBT rights in the context of the age of consent, freedom of assembly, expression and association, adoption, parental rights and obligations, housing tenure, social and employer benefits, military service, residence permits and extradition, gender reassignment, dress code, blood donation, registration of partnerships, personal refusal of service to LGBT persons and violence and the lack of investigation thereof. ${ }^{48}$ This indicates that the European system has moved well beyond the negative approach to sexual orientation and gender identity based on the right to privacy towards a positive approach by cementing the entitlement to equality based on sexual orientation and gender identity.

The aim of this article is not to provide an in-depth account of either soft law or the jurisprudence of the European Court relating to sexual orientation, but rather to indicate that the African regional human rights system in its consideration of issues relating to sexual orientation is existing and acting within, what I would argue to be, a very defined context. It is true that international law does not generally recognise the effect of precedents and, therefore, the jurisprudence of the other regional courts are of persuasive value only. However, the developments under the European and American Conventions, the latter being the focus of the following section, represent not only regional developments, but also the outcome of a broader development of international human rights law. In conjunction, these developments arguably have to have some effect on how we understand the position of sexual orientation on the African continent. In the following section, I engage with a deeper analysis of process and merits claims relating to sexual orientation within the context of the Inter-American system.

\section{Imperative developments under the Inter-American system - The Atala case}

The Inter-American human rights system has dealt with three cases 49 relating to human rights violations on the basis of sexual orientation.

46 Norris v Ireland ECHR (26 October 1988) Ser A 142; Modinos v Cyprus ECHR (22 April 1993) Ser A 259; Lustig-Preen and Beckett v UK (2000) 29 ECHR 548.

47 Salgueiro da Silva Mouta v Portugal ECHR (21 March 2010) Ser A 741.

48 See ECHR Factsheets on 'Sexual orientation issues' March 2014 http:// www.echr.coe.int/Documents/FS_Sexual_orientation_ENG.pdf; 'Homosexuality: Criminal aspects' November $2013 \mathrm{http} / / /$ www.echr.coe.int/Documents/FS_Homo sexuality_ENG.pdf; 'Gender identity issues' October 2013 http://www.echr. coe.int/Documents/FS_Gender_identity_ENG.pdf (accessed 27 March 2015).

49 Marta Lucia Alvarez Giraldo v Colombia Inter-American Commission of Human Rights, IAm Comm of HR, (4 May 1999), OEA/SerL/V/II 106 Doc 3 rev 211, Karen 
One of the cases, the Atala case, ${ }^{50}$ was heard firstly by the InterAmerican Commission and was then referred to the Inter-American Court. Both bodies made important findings discussed below. The Atala case concerned Mrs Atala and her three daughters. When Mrs Atala and her husband decided to separate after nine years of marriage, both parties agreed that their daughters should remain with Mrs Atala. However, when Mrs Atala the following year moved in with a new, female, partner, the girls' father filed a complaint with a local court claiming that the children would be harmed if they continued living in their home with their lesbian mother and her new partner. The case made its way through the Chilean courts, and the Supreme Court handed down judgment in May 2004. In this judgment, three of the five justices on the bench characterised the daughters as being in a 'situation of risk' that placed them in a 'vulnerable position in their social environment, since clearly their unique family environment differ[ed] significantly from that of their school companions'. ${ }^{51}$

Later in 2004, Mrs Atala filed a petition with the Inter-American Commission. The case was declared admissible before the Commission, 52 and a unanimous court later found that Chile was responsible for a violation of the right to equality and nondiscrimination enshrined in article 24, in conjunction with article 1(1) of the American Convention on Human Rights (American Convention), to the detriment of Mrs Atala. The Inter-American Court concluded: ${ }^{53}$

Bearing in mind the general obligations to respect and guarantee the rights established in article 1(1) of the American Convention, the interpretation criteria set forth in article 29 of that Convention, the provisions of the Vienna Convention on the Law of Treaties, and the standards established by the European Court and the mechanisms of the United Nations ... the sexual orientation of persons is a category protected by the Convention. Therefore, any regulation, act or practice considered discriminatory based on a person's sexual orientation is prohibited. Consequently, no domestic regulation, decision, or practice, whether by state authorities or individuals, may diminish or restrict, in any way whatsoever, the rights of a person based on his or her sexual orientation.

Atala and Daughters $v$ Chile Inter-American Commission of Human Rights, IAm Comm of HR (23 July 2008) OEA/Ser L/V/II130 Doc 22 Rev 1, Atala (n 31 above) and. Ángel Alberto Duque $v$ Colombia, Inter-American Commission of Human Rights, IAm Comm of HR, (2 November 2011), Case 123-05, Report 150/11.

$50 \mathrm{n} 31$ above.

51 Judgment of the Supreme Court of Justice of Chile (31 May 2004) para 12, as quoted in Atala (n 31 above) para 57. In its decision, the Supreme Court of Justice revoked from Mrs Atala the custody of her three daughters.

52 Karen Atala and Daughters $v$ Chile, Inter-American Commission of Human Rights ( 31 above) para 69.

53 Atala (n 31 above) para 314. 


\section{The African Charter on Human and Peoples' Rights in perspective}

The Atala case is undoubtedly a landmark case in the protection of gay and lesbian rights. It brought together the developments on the international and European levels and cemented the right to equality under the concept of jus cogens. It further refuted the common objections to sexual orientation as a ground for non-discrimination and highlighted the need for sexual orientation to be viewed as a suspect category. This case is relevant to the African Commission and Court for a number of reasons. Firstly, the sources of law are very similar in substance, as anchored in the Universal Declaration, and rooted in similar contexts. Secondly, the Commission has on numerous occasions either itself referred to the reports of the InterAmerican Commission and the judgments of the Court in its decisions or accepted these sources as introduced either by the complainant or the state. ${ }^{54}$ Thirdly, the jurisdiction of the Court would not exclude case law from other regional courts presiding over human rights instruments of similar content to constitute persuasive value, as indicated in articles 2 and 3 of the Protocol and article 61 of the African Charter. This is furthermore evident in the separate opinion of Judge Ouguergouz in Yogogombaye $v$ the Republic of Senegal, ${ }^{55}$ where he uses practice of the Inter-American Commission, the InterAmerican Coourt and the European Court to substantiate his reasoning.

The application of the American Convention by the Inter-American Court is helpful because it sets out an analytical structure which could be used successfully within the context of the African Charter. If the discriminatory laws are considered from the perspective of its respective outcomes, it is clear that they create a category of persons who, by their very nature, regardless of their behaviour, would have no or limited protection of their privacy and liberty; who would not be able to engage in sexual activities of their choice, to openly kiss or touch a loved one, to marry or associate with other individuals over common causes or to speak freely.

There are four immediate features of the African Charter read together with the African Women's Protocol and the African

54 See eg Majuru v Zimbabwe (2008) AHRLR 146 (ACHPR 2008) para 59; Mouvement Ivoirien des Droits Humains (MIDH) v Côte d'Ivoire (2008) AHRLR 75 (ACHPR 2008) para 48; Zimbabwe Lawyers for Human Rights \& Another v Zimbabwe (2008) AHRLR 120 (ACHPR 2008) paras 64-65, 67, $69 \& 79-80$, Article $19 v$ Eritrea (2007) AHRLR 73 (ACHPR 2007) paras 51 \& 75; Social and Economic Rights Action Centre (SERAC) \& Another v Nigeria (2001) AHRLR 60 (ACHPR 2001) para 57.

55 African Court on Human and Peoples' Rights Yogogombaye $v$ the Republic of Senegal Application 001/2008, separate opinion of judge Fatsah Ouguergouz http://www1.chr.up.ac.za/images/files/documents/africancases/institution/african court/yogogombaye_v_senegal_separate_opinion_2008.pdf (accessed 8 February 2015). 
Children's Charter that become relevant within the context of the Atala case: firstly, the reference to 'other status' in article 2,56 and the reference to 'every individual' in article $3(2)^{57}$ with regard to equality before the law; secondly, the lack of protection of privacy in the African Charter and the African Women's Protocol; the protection of privacy is, however, notably prescribed in article 10 of the African Children's Charter. Thirdly, the rights of dignity and liberty alongside freedoms of expression, speech and association are protected; and, fourthly, article 27(2) expresses the possibility of a limitation of the rights in the African Charter. The Charter presents a very similar approach to these basic human rights as the American and European Conventions and other international conventions, such as the $\mathrm{ICCPR}^{58}$ that further strengthens the analogy attempted.

\subsection{Non-discrimination and equality before the law}

In the application to the Inter-American Court, ${ }^{59}$ the Inter-American Commission used a four-pronged approach to the issue of equality. It firstly considered the interrelation, scope and content of articles 1.1 and 24 of the American Convention (mirroring articles 2 and 3 of the African Charter). Secondly, it considered the differences in treatment, suspect categories, and the strict scrutiny test. Thirdly, the InterAmerican Commission explored sexual orientation as a suspect category for distinction; and, fourthly, it undertook a specific analysis of the case at hand, including a discussion about the separate rights and the possibility of a limitation of such rights. ${ }^{60}$

In analysing the first prong of the methodological approach in the context of the African Charter, it is important to acknowledge the Preamble of the Charter. Part of it reads: 'Recognising ... that fundamental human rights stem from the attributes of human beings which justifies their national and international protection ...', indicating that it is not a set of African values or national laws that dictate the contents and context of any given human right, such as equality. Arguably, the phrase 'attributes of human beings' expresses the widest possible diversity in determining fundamental human rights. The right not to be discriminated against is one of the most basic rights resonating in most national constitutions and international human rights instruments alike. It is furthermore a right erga omnes and part of the concept of jus cogens and, as indicated by the InterAmerican Court in the Atala case in stating that ' $[\mathrm{t}] \mathrm{he}$ juridical

56 With similar reference in arts $1 \& 2$ of the African Women's Protocol and art 3 of the African Children's Charter.

57 With similar reference in art 8 of the African Women's Protocol.

58 On the African continent it is only South Sudan that is not a state party to the ICCPR.

59 IAComHR Application 12.502 in the case of Karen Atala and Daughters $v$ Chile http://www.cidh.oas.org/demandas/12.502ENG.pdf (accessed 13 February 2015).

$60 \quad$ Atala (n 59 above) para 72. 
framework of national and international public order rests on this principle and permeates the entire legal system'. ${ }^{61}$

Discrimination as such is not referred to in the African Charter (or the American Convention). ${ }^{62}$ Article 2 of the African Charter instead refers to 'distinction'. It is in this regard useful to use the definitions contained in the Convention on the Elimination of all Forms of Racial Discrimination (CERD) and the Convention on the Elimination of all Forms of Discrimination Against Women (CEDAW) characterising discrimination as ${ }^{63}$

[any] distinction, exclusion, restriction or preference which is based on any ground ... and which has the purpose or effect of nullifying or impairing the recognition, enjoyment or exercise by all persons, on an equal footing, of all rights and freedoms.

It is an established rule that not all differentiation in treatment violates the rights to non-discrimination and equality. As expressed by the Inter-American Commission, international judicial and quasi-judicial bodies use certain established tests to evaluate the reasonable and objective reasons for the difference in treatment. However, before such a test can be performed, it has to be determined whether sexual orientation is a suspect category which would require of any state, differentiating on this ground, to substantiate and explain why it would be reasonable and just to do so. In line with the reasoning of Murray and Viljoen and as argued by Goldstone $J$ in Harksen $v$ Lane NO \& Others, ${ }^{64}$ a new ground for non-distinction, that is, sexual orientation, could be invoked because non-discrimination based on sexual orientation or gender identity impairs the inherent human dignity in a manner which is serious and comparable to the factors, such as sex or social origin, that are already listed. As discussed above, international soft law protects against discrimination based on sexual orientation. Moreover, homosexual persons are protected by the equality clauses in the constitutions of their countries of origin or domicile, the equality clause in the regional agreements and the equality clauses as set out in a number of international human rights instruments, such as the ICCPR, the International Convention on Economic, Social and Cultural Rights (ICESCR), CEDAW, the Convention on the Rights of the Child (CRC) and the Convention Against Torture and Other Cruel, Inhuman or Degrading Treatment or Punishment (CAT). In the Atala case, the Inter-American Commission established: 65

[S]exual orientation is covered by the phrase 'other social condition' contained in article 1.1, with all the consequences that this implies with

61 n 31 above, para 79.

62 It is, however, well defined in arts 1 and 2 of the African Women's Protocol.

63 Art 1(1) CERD and art CEDAW. See also arts 1 and 2 of the African Women's Protocol.

641998 (1) SA 300 (CC) para 46.

65 IAComHR Application (n 59 above) para 95. 
respect to the other rights enshrined in the American Convention, including article 24. Therefore, a difference in treatment based on a person's sexual orientation is suspect; it is presumed to be incompatible with the American Convention; and the corresponding state is obliged to prove that it passes the strict scrutiny test ...

There is evidently enough evidence to be able to conclude that 'sex and other grounds' include discrimination based on sexual orientation and/or gender identity and that unjust differentiation based on these criteria is deemed discrimination by the UN, the Inter-American Court and the European Court. Thus, it is impossible to fathom how the African Commission, under the African Charter, could deviate from this established norm, even more so in the light of Resolution $275^{66}$ as passed by the African Commission in May 2014 and its decisions in Zimbabwe Human Rights NGO Forum (as discussed above) and Purohit $\&$ Another $v$ The Gambia. ${ }^{67}$

In Purohit, the African Commission clearly showed its willingness and ability to find corresponding grounds not specifically listed in article 2 of the African Charter. The case concerned the inclusion of disability under article 2 as an analogous ground. In its decision, the Commission argued that, in interpreting and applying the African Charter, the Commission relies on its own jurisprudence and, as provided for by articles 60 and 61 of the Charter, on appropriate and relevant international and regional human rights instruments, principles and standards. It furthermore indicated that it was willing to accept legal arguments with the support of appropriate and relevant international and regional human rights instruments, principles, norms and standards, taking into account the well-recognised principle of universality which is established by the Vienna Declaration and Programme of Action of 1993. It further stated: 68

[A]rticles 2 and 3 of the African Charter basically form the antidiscrimination and equal protection provisions of the African Charter. Article 2 lays down a principle that is essential to the spirit of the African Charter and is therefore necessary in eradicating discrimination in all its guises, while article 3 is important because it guarantees fair and just treatment of individuals within a legal system of a given country. These provisions are non-derogable and therefore must be respected in all circumstances in order for anyone to enjoy all the other rights provided for under the African Charter.

In Purohit, the African Commission found The Gambia to have violated the African Charter based on the discrimination against disabled persons. This case is not only important because it shows the

66 Resolution 275 'On Protection against Violence and other Human Rights Violations against Persons on the Basis of their Real or Imputed Sexual Orientation or Gender Identity', African Commission on Human and Peoples' Rights, meeting at its 55th ordinary session held in Luanda, Angola, from 28 April to 12 May 2014, http:// www.achpr.org/sessions/55th/resolutions/275/ (accessed 3 February 2015) (Resolution 275).

67 (2003) AHRLR 96 (ACHPR 2003).

68 Purohit (n 67 above) para 49. 
possibilities of an analogous ground and the ease with which the Commission accepted this argument, but also its willingness to utilise soft law in concluding the matter before it. The argument of the existence of analogous grounds under article 2 of the African Charter was furthermore confirmed in Bissangou $v$ Republic of Congo, ${ }^{69}$ where the Commission indicated that grounds similar in nature to those listed in article 2 would be relevant in a claim of discrimination under the African Charter.

\subsection{Violations}

When departing from the approach set out in Atala, it becomes clear that any law criminalising consensual same-sex sexual acts violates the right to dignity. As was indicated by the African Commission in the Purohit case, ${ }^{70}$ human dignity is an inherent basic right which all human beings are entitled to without discrimination. In Media Rights Agenda $v$ Nigeria' $^{71}$ the Commission held that the term 'cruel, inhuman or degrading punishment and treatment' is to be interpreted so as to extend to the widest possible protection against abuses, whether physical or mental. Furthermore, in Modise $v$ Botswana, ${ }^{72}$ the African Commission stated that exposing victims to 'personal suffering and indignity' violated the right to human dignity. Personal suffering and indignity can take many forms, as is evident in the context of the realities of homosexual persons, for example in Uganda and Nigeria. The discriminatory laws create systems of denunciation similar to the ones used in Nazi Germany and apartheid South Africa to locate and imprison citizens either engaging in samesex or inter-racial relationships. Discriminatory laws force persons, under the threat of imprisonment, to denounce non-heterosexual marriages and gay clubs, societies or organisations. Discriminatory laws furthermore motivate partners to turn on each other if it is discovered that they have engaged in a homosexual act. As reported by the International Gay and Lesbian Human Rights Commission (IGLHRC), blackmail and harassment of gays and lesbians are rife in sub-Saharan Africa and legislation of this nature aggravates an already critical situation. ${ }^{73}$ This amounts to a clear violation of the right to dignity, as set out in article 5 of the African Charter as well as in article 3 of the African Women's Protocol.

69 (2006) AHRLR 80 (ACHPR 2006) para 69.

70 Purohit (n 67 above) para 57.

71 (2000) AHRLR 262 (ACHPR 2000) para 71.

72 Modise v Botswana (2000) AHRLR 30 (ACHPR 2000).

73 IGLHRC Report (n 22 above) 5-6. 
Ingrained in the right to dignity is also the right to privacy. The right to privacy has been one of the most important rights in the process of declaring national anti-sodomy laws contrary to basic human rights. ${ }^{74}$ As was indicated above, the right to privacy is not explicitly spelled out in the African Charter but, as discussed by Viljoen and Murray, ${ }^{75}$ it can be understood as an implied right under the right to dignity in line with the arguments in the case of SERAC. ${ }^{76}$ This was furthermore highlighted in Atala, where the Inter-American Court established that privacy fell under the ambit of the protection of dignity. It further concluded that privacy was an ample concept that was not subject to exhaustive definitions and includes, among other protected realms, the sex life and the right to establish and develop relationships with other human beings. Therefore, privacy includes the way in which the individual views himself and to what extent and how he or she decides to project this view to others. ${ }^{77}$ The issue of privacy is, however, a double-edged sword: On the one hand, it is the path of least resistance in that it would not force states such as Nigeria and Uganda to explicitly 'accept' homosexuality. Privacy can be used to encapsulate a 'derogatory' behaviour, while at the same time arguing that as long as it is hidden, it would not be accepted but just ignored. On the other hand, the use of privacy would leave the stigma completely untouched and the state without any positive obligations towards homosexual persons. Furthermore, some of the acts criminalised in the discriminatory laws are by their nature public acts. Same-sex amorous expression and advocating for gay rights are amongst the acts that are criminalised and, in this context, the right to privacy would arguably have very little effect.

Articles 4 and 6 of the African Charter, furthermore, spell out the essential rights to life and integrity well as the right of every person to liberty and security of the person. ${ }^{78}$ These rights can be restricted under article 27(2) and the right to liberty and security of the person can additionally be restricted under certain circumstances in conjunction with the claw-back clause inserted in article 6. Both provisions, however, refer to the strict prohibition of an arbitrary depravation of these rights. As pointed out by Ouguergouz, ${ }^{79}$ the word 'arbitrarily' does not have the same meaning as 'illegal'; it is

74 See Lawrence $v$ Texas 539 US 558 (2003); Toonen (n 42 above) and Croome v Tasmania 191 CLR 119 (1997).

75 Murray \& Viljoen $\mathrm{F}$ (n 37 above) 89-90.

76 SERAC (n 54 above).

77 Atala (n 31 above) para 162.

78 With similar reference in art 4 of the African Women's Protocol and art 5 of the African Children's Charter.

79 F Ouguergouz The African Charter of Human and People's Rights: A comprehensive agenda for human dignity and sustainable democracy in Africa (2003) 93. 
broader. In the same vein, the International Court of Justice (ICJ) in the Elettronica Sicula case ${ }^{80}$ 'stipulated: $: 11$

Arbitrariness is not so much something opposed to a rule of law, as something opposed to the rule of law. It is a wilful disregard of due process of law, an act which shocks, or at least surprises, a sense of juridical propriety.

From this perspective, it is important to note that the principle of nondiscrimination is not only a well-established legal principle, but it is a jus cogens norm, as recognised by the Inter-American Court in Atala. ${ }^{82}$ Article 29(2) of the Universal Declaration expresses that

[i]n the exercise of his rights and freedoms, everyone shall be subject only to such limitations as are determined by law solely for the purpose of securing due recognition and respect for the rights and freedoms of others and of meeting the just requirements of morality, public order and the general welfare in a democratic society.

From the above, it is possible to draw two conclusions. Firstly, if a person's rights are limited based only on that person's sexual orientation and/or gender identity, that would constitute an arbitrary depravation or limitation of that right. Secondly, when it has been established that a right has been arbitrarily deprived or limited, none of the reasons that might fit under article 27(2) - or the 'claw-back' clauses with regard to the nature or reasons of the law, as further discussed below - relieves this fact. In short, it is impossible to justify arbitrariness with morality or common interest. This would lead to the conclusion that if a person's integrity, liberty or security is limited or taken away due to that person's sexual orientation, that person has been arbitrarily deprived of said rights. Similarly, if a person is subjected to a law that would require other individuals to denounce that person's most intimate and private acts and thoughts, solely based on that person's sexual orientation, that would be an arbitrary infringement on that person's integrity. Hence, an act prescribing such actions would violate articles 2 and 4 of the African Charter.

It is furthermore essential to note that it would also be possible to explore the prohibition of same-sex marriages under the African Charter in relation to the principles of equality before the law and of equal protection of the law. The discussion above has centred on rights that are protected in the African Charter and their relationship with the right to non-discrimination. There is no right to marriage in the Charter. However, a law that prohibits marriage solely on a suspect ground is in violation of the right to equality before the law. As was stated by Sachs J in Minister of Home Affairs \& Another v Fourie

80 Case concerning Elettronica Sicula SPA (ELSI) United States of America $v$ Italy (20 July 1989) (1989) ICJ Reports.

81 n 80 above, para 128.

82 Atala (n 31 above) para 79. 
$\& A n o t h e r,{ }^{83}$ in interpreting the right to equal protection by the law: 84

At the very least, then, the applicants in both matters are entitled to a declaration to the effect that same-sex couples are denied equal protection of the law under section 9(1), and subjected to unfair discrimination under section 9(3) of the Constitution, to the extent that the law makes no provision for them to achieve the dignity, status, benefits and responsibilities available to heterosexual couples through marriage.

Discriminatory laws furthermore violate a number of freedoms as set out in the African Charter, the African Women's Protocol and the African Children's Charter, namely, freedom of expression, association and assembly. Discriminatory laws prohibit gay clubs, societies, organisations, processions and meetings and, additionally, any person or organisation that funds these types of bodies. These restrictions are only based on sexuality, that is, the laws refer to 'gay' clubs or 'a person who abets homosexuality', clearly indicating a violation of the rights set out, based on sexual orientation. It is within this context that article 27(2) of the African Charter and the 'claw-back' clauses may become relevant. The tests set out by the African Commission and the Inter-American Commission are again useful. Article 27 stipulates that rights and freedoms have to be 'exercised with due regard to the rights of others, collective security, morality and common interest'. This is not a limitation clause per se, but refers to the duties of every individual vis-à-vis other individuals. Even if this is not a limitation clause in the stricter sense, it has been applied to justify limitations. In this regard, the African Commission has expressed that: $: 5$

The reasons for possible limitations must be founded in a legitimate state interest and the evils of limitations of rights must be strictly proportionate with and absolutely necessary for the advantages which are to be obtained. Even more important, a limitation may never have as a consequence that the right itself becomes illusory.

This provision should be viewed in light of the decision of the African Commission in Article 19 v Eritrea, ${ }^{86}$ where the Commission stated that '[i]nternational human rights standards must always prevail over contradictory national law' and '[a]ny limitation on the rights of the Charter must be in conformity with the provisions of the Charter'. ${ }^{87}$

In the context of discriminatory laws, three main arguments have been used to justify these laws: moral values (mainly based either on religion or traditional African values); the threat to the heterosexual family; and the dangers presented to the welfare of children and the

832006 (1) SA 524 (CC).

84 Fourie (n 83 above) para 79.

85 Media Rights Agenda \& Others v Nigeria (2000) AHRLR 200 (ACHPR 1998) paras 69-70.

86 (2007) AHRLR 73 (ACHPR 2007) para 105.

87 Article 19 (n 86 above) para 105. 
youth. As mentioned above, in trying to evaluate whether a distinction is 'reasonable and objective' (that is outside the scope of arbitrariness as discussed above), the Inter-American Commission, the Inter-American Court and other international courts and bodies have similarly made use of standard tests involving certain requirements. These tests include, for example, the existence of a legitimate goal; the relation between the goal sought and the distinction; the existence of other alternatives; and the proportionality, understood as the balance between the interests at stake and the level of sacrifice required from one party compared to the level of benefit of the other. $^{88}$ In the Atala case, the Inter-American Commission and the Inter-American Court found that the different treatment that Mrs Atala was subjected to during the custody proceedings 'was not justified by a pressing social need and did not comply with the requirements of suitability, necessity, and proportionality' ${ }^{\prime}{ }^{8}$

From the perspective of the discriminatory laws, it is initially imperative to note the basic yet significant statement in Article 19 that the standards of the African Charter must always prevail over national legislation and limitations can only be made at the satisfaction of the Charter. When engaging with the justifications, in other words the reference to moral values, it immediately becomes clear that there is very little legal substance in these justifications. What would be the legitimate goal sought to be achieved by this type of discriminatory law? As an example, the motive of the Anti-Homosexuality Act is spelled out in the AHA Bill. It is to '[s]trengthen the nations' capacity to deal with the emerging internal and external threats to the traditional heterosexual family' and to 'protect the children and youth'. ${ }^{90}$ Similar objectives have been raised with regard to the SameSex Marriage (Prohibition) Act.

Moreover, in Atala, the Inter-American Commission and the InterAmerican Court discussed the justification of a distinction on sexual orientation grounded on a pressing social need. In that case, it referred mainly to whether Mrs Atala's daughters would suffer any harmful consequences by being brought up in a household with two women instead of a man and woman. In the context of the discriminatory laws, it would refer to whether, on the one hand, upholding the majority values of heterosexuality and, on the other, saving the youth and the heterosexual family would be such a pressing social need. In Atala, the Court found no harm in a lesbian mother bringing up her children within her lesbian relationship, just as no correlation exists between a non-heterosexual orientation and the harm that has been suggested to children and heterosexual marriages in Uganda and Nigeria. Arguably, there is no pressing social need to save children and heterosexual married couples in Nigeria or

88 IAComHR Application (n 59 above) para 86.

89 IAComHR Application, para 101.

90 AHA Bill (n 12 above) 3.0, The objectives of the Bill. 
Uganda from people with a same-sex orientation or a gender identity that does not fit in with the male-female binary. No limitations can, therefore, be made on these grounds simply because they would not comply with the requirements of 'suitability, necessity and proportionality' ${ }^{91}$

\subsection{Avenues to the African Court}

Previously, the monitoring of the African Charter rested solely on the different mechanisms available under the mandate of the African Commission. With the development and inclusion of the African Court, there is potential to move beyond the non-binding decisions of the Commission toward legally-binding decisions and advisory opinions on specific legal issues. ${ }^{92}$ Of importance is the close relationship that is created between the Commission and the Court as set out in the Protocol ${ }^{93}$ and the 2010 Rules of Procedure of the African Commission. ${ }^{94}$ The objective of the discussion below is to outline the possibilities of the Commission and Court taking a similar procedural approach as the Inter-American Commission and Court in Atala. I focus on the African Commission's mandate to bring such a case to the African Court, as the Inter-American in Atala, alternatively, the mandate of any individual or NGO to do the same.

In Atala, the Inter-American Commission accepted and investigated Mrs Atala's claims and under its mandate it proceeded to present the case to the Inter-American Court based on the report. The procedural avenues to the Inter-American Court and the African Court are not identical, but similar enough, to justify a discussion. Importantly, both the Inter-American Commission ${ }^{95}$ and the African Commission may present cases to the relevant courts and, in addition, the African system allows individuals and NGOs to present claims if the state party has recognised the African Court's jurisdiction in this regard. On face value, the African system could and should offer more opportunities for complaints to reach the African Court than the InterAmerican system, considering the direct and indirect access to the African Court, as discussed below. However, this is not the reality thus far. In analysing the relationship between the African Commission and the Court, I depart from the assumption that both the Commission and the Court, in fulfilling their separate yet interlinked mandates, need not only to uphold the African Charter and related regional instruments, but also position themselves in line with comparable

91 IAComHR Application (n 59 above) para 101.

92 This would, however, also relate to the willingness of the AU Assembly to utilise its mandate as spelled out in arts $3,4,9(1)(e)$ and 23(2) of the AU Constitutive Act.

93 Art 2.

94 Rules 114-123.

95 The American Convention only allows state parties and the IAComHR to file complaints with the IACHR under art 61. According to art 61(2) of the American Convention, the procedure in arts 48 and 50 has to be followed for the IAComHR to be able to lodge such a complaint. 
international instruments and the recognised interpretations thereof. ${ }^{96}$ From this perspective, it becomes possible to argue, firstly, that the African Commission as a guardian ${ }^{97}$ of the African Charter has the obligation to advance positive rights of homosexual persons in Africa. Secondly, the African Commission and African Court should protect all Africans against the infringement of their rights. Thirdly, the obligation to promote equality does not only involve advocating non-infringement but also a positive duty, reaching beyond the issue of privacy.

Other scholars have dealt with the position of the African Commission on gay and lesbian rights in detail, ${ }^{98}$ and it suffices to say that previously the Commission on occasions has adopted what is strikingly referred to by Viljoen and Murray as the position of 'quiet accommodation'. ${ }^{99}$ This approach was, however, abruptly interrupted when the Commission denied the Coalition of African Lesbians (CAL) observer status in 2010. In that decision, the Commission stated that 'the activities of the said organisation [did] not promote and protect any of the rights enshrined in the African Charter'. ${ }^{100}$ The opinion expressed by a majority of commissioners in the CAL matter in 2010 arguably left very little room for any complaint of discrimination based on sexual orientation to be considered by the Commission. The course of the Commission, however, changed at its last, 56th session, where CAL was finally granted observer status. ${ }^{101}$ The 2015 CAL decision has possibly returned the African Commission to its obiter opinion expressed in Zimbabwe Human Rights Forum. ${ }^{102}$

Furthermore, in Resolution 275, the African Commission focused specifically on violence against homosexual persons and referred directly to articles 2, 3, 4 and 5 of the African Charter. The Commission strongly urged states to endorse and effectively apply ${ }^{103}$

appropriate laws prohibiting and punishing all forms of violence including those targeting persons on the basis of their imputed or real sexual orientation or gender identities, ensuring proper investigation and diligent prosecution of perpetrators, and establishing judicial procedures responsive to the needs of victims.

This shows that the Commission has accepted that violence on the basis of sexual orientation amounts to discrimination and violates the

96 Art 7 African Women's Protocol and arts $60 \& 61$ African Charter.

97 Art 45 African Charter.

98 Murray \& Viljoen (n 37 above); Viljoen (n 34 above).

99 Murray \& Viljoen (n 37 above) 86.

100 See the 28th Activity Report of the African Commission AU Doc EX.CL/600 (XVII) para 33, as quoted in Viljoen (n 34 above) 266.

101 See the 56th Activity Report of the African Commission, http://www.achpr.org/ sessions/56th/info/communique56/ (accessed 29 May 2015), see also AU Doc.EX.CL/856(XXV).

102 n 35 above, para 169. In this decision, the African Commission stated that 'the aim of [equality and non-discrimination] is to ensure equality of treatment for individuals irrespective of ... sexual orientation'.

103 Resolution 275 (n 66 above) para 4. 
rights to equality, integrity and dignity. This, however, does not mean that the Commission has accepted non-discrimination based on sexual orientation. It is furthermore important to note that the Commission, in the Resolution, refers to 'the creation of enabling environment that is free of stigma, reprisals or criminal prosecution'. ${ }^{104}$ This could be understood as indicating a broader undertaking by state parties targeting other forms of discrimination based on sexual outside the ambit of violent crimes as well as a further understanding of the effects of laws that discriminate on the basis of sexual orientation. This, however, needs further clarification from the Commission. In light of these statements, there appears to have been a drastic change of approach of the Commission, as confirmed by the 2015 CAL decision. It, however, remains unclear how the Commission would approach an individual claim of discrimination based on sexual orientation under the African Charter.

\subsubsection{Locus standi}

Articles $5^{105}$ and $34(6)^{106}$ of the Protocol regulate locus standi before the African Court. Read in conjunction, they create three possible ${ }^{107}$ scenarios as to who or what entity can bring complaints before the Court. The African Commission, 08 an individual ${ }^{109}$ or an NGO accredited with the Commission can file a complaint. In light of the 2015 CAL decision and the more protective position in Resolution 275, there are reasons to be optimistic about the Commission's approach to gay and lesbian rights. It is, however, still impossible to conclude whether it would act as a conduit to the Court, given the right circumstances, in such a claim. A communication will only be considered and subsequently referred to the African Court if a majority of the commissioners are in favour of it. ${ }^{110}$ It is essential to note that, should the Commission fail in this regard, it would fail two of its most important mandates under the Protocol: firstly to fulfil its role to ensure the protection of all human rights under the African

104 Resolution 275 (n 66 above) para 3.

105 Art 5 grants the Commission, a state party which has lodged a complaint to the Commission, a state party against which the complaint has been lodged at the Commission, a state party whose citizen is a victim of human rights violation and African intergovernmental organisations the right to submit a case to the Court.

106 The Court may furthermore entitle relevant NGOs with observer status before the Commission and individuals to institute cases directly before it if the relevant state has made a declaration accepting the Court's jurisdiction in this regard.

107 This argument ignores the unlikely scenario where a state party whose citizen is a victim of a human rights violation would bring a case to the Court.

108 The Committee on the Rights and Welfare of the Child would also be able to bring cases to the Court as it qualifies as an African intergovernmental organisation under art 5(1)(e). See Viljoen (n 34 above) 407. According to Rule 118(4) of the 2010 Rules of Procedure, ' $[\mathrm{t}]$ he Commission may seize the Court at any stage of the examination of a communication if it deems necessary'.

109 Does not have to be the victim. There are no victim requirements in the African Charter or the African Women's Protocol.

110 Art 55(2) African Charter. 
Charter; and, secondly, to act either as a conduit to the Court for NGOs and individuals claiming violations by states that have not made a 34(6) declaration, or by bringing cases to the Court under its own mandate.

Furthermore, Nigeria, Uganda and The Gambia have not made a 34(6) declaration under the Protocol. It is, therefore, unlikely that the African Court would accept a complaint from any individual or NGO directly or indirectly affected by the discriminatory legislation, as discussed above. This is a fundamental weakness of the African human rights system, as pointed out by the dissenting judges in Femi Falana $v$ African Union ${ }^{111}$ and Atabong Denis Atemnkeng $v$ African Union. ${ }^{112}$ It is ostensible that the ability of individuals and NGOs to complain directly to the Court was traded off against the increased willingness of states to commit to the Protocol without the immediate burden of having to face aggrieved individuals in court. This, in itself, as indicated by the dissenting opinion in Atabong Atemnkeng, could be viewed as a limitation of the right of access to justice. ${ }^{113}$ The African Commission, acting as a conduit to the African Court when the option of direct access is not available, could partly weigh up this deficiency. Thus far, the Commission has only referred two cases to the Court. ${ }^{114}$

\section{Conclusion}

The significant outcomes of Atala are difficult to ignore. The InterAmerican Court approached sexual orientation in a holistic way and substantiated existing jurisprudence and soft law, leaving the 35 member states of the Organisation of American States with little doubt about the scope of the non-discrimination clauses in the American Convention and American Declaration of the Rights and Duties of Man. It will be difficult for any commissioner at the African Commission or any judge at the African Court to ignore the compelling arguments presented in Atala. However, the question remains whether a case of discrimination based on sexual orientation can make its way to the Court under the present circumstances. The bleak outlook highlighted in this article clearly indicates that very few avenues are currently open to individuals living in fear and indignity under discriminatory laws. The Inter-American Court (with the assistance of the Inter-American Commission) and the European Court have, however, demonstrated that judges have the power to chart the

11126 June 2012.

11215 March 2013, referring to the dissenting opinion of Justices Akuffo (President), Ngoepe and Thompson.

113 As above.

114 African Commission on Human and Peoples' Rights $v$ The Great Socialist Peoples' Libyan Jamahiriya, 15 March 2011 and African Commission on Human and Peoples' Rights $v$ Republic of Kenya, pending. 
territory of the courts and to apply its procedural rules and substantive law to promote the protection of all human rights.

Key to the process of expanding the scope of the African Charter is the ability of the African Union (AU) to elect competent judges. Individuals that serve on the African Commission and African Court are elected using a similar process: Individuals are nominated by state parties and elected by the Assembly of Heads of States and Government of the AU. ${ }^{115}$ While there is very little material by which it is possible to determine the attitudes of the judges of the Court thus far, the nature of the position of a judge is much different from that of a commissioner, which could prove to be relevant. The Court is populated by judges who, contrary to the commissioners, are prohibited from participating in any activity of a nature that will compromise the independence and impartiality of the judge. ${ }^{116}$ Article 5 of the Rules of Court, moreover, states that no judge may 'hold a political, diplomatic or administrative position or function as government legal adviser at the national level'. No such requirements are placed on the commissioners. Arguably, the judges of the Court, similarly to the judges on the Inter-American Court, should approach matters before them based on the law within its jurisdiction and other relevant sources, as spelt out in the Protocol and the African Charter with the aim to uphold and protect all human rights. In doing so, they should act separately from the states that have set up this monitoring mechanism to achieve the essential purposes of the Constitutive Act of the AU to promote and protect human and peoples' rights in accordance with the African Charter and other relevant human rights instruments. ${ }^{117}$ Udombana has expressed hope that the Rules of Court would be 'broad, flexible and creative so that the purposes of the Banjul Charter will not be defeated by mere technicalities'. ${ }^{118}$ In the context of building a case around the discriminatory laws discussed in this article, the need for this approach could not be more pressing. Not only is there a need for the Court to borrow from its counterparts in the inter-American and European systems with regard to the interpretation of the law, but also in its holistic approach to the law, embracing both access and outcomes. As former Judge Picado Sotela of the Inter-American Court reflected: ${ }^{19}$

[A] court of human rights should be much more flexible than a regular court ... The international law of human rights is broader [than international law], and it should have more possibilities to really apply the principles of human rights. If we are going to believe in the enforcement of human rights, we have to take an attitude that is not very positivistic or legalistic, but instead [is in] the spirit of the law in the defence of human

115 Art 33 African Charter and arts 12-14 African Women's Protocol.

116 Art 18 African Women's Protocol.

117 Art 3(h)

118 NJ Udombana 'Toward the African Court on Human and Peoples' Rights: Better late than never' (2000) 3 Yale Human Rights and Development Law Journal 106.

119 LE Frost 'The evolution of the Inter-American Court of Human Rights: Reflections of present and former judges' (1992) 14 Human Rights Quarterly 185. 
beings. In this sense, the judge should believe that a court of human rights is obligated to create jurisprudence ... I believe that the court has the obligation to look for openings, because in reality these are new cases and different situations.

In the judgment of the Inter-American Court in Atala, the Court found such openings when it considered that ${ }^{120}$

[h] uman rights treaties are living instruments, whose interpretation must go hand in hand with evolving times and current living conditions. This evolving interpretation is consistent with the general rules of interpretation set forth in article 29 of the American Convention, as well as those established in the Vienna Convention on the Law of Treaties. In this regard, when interpreting the words 'any other social condition' of article 1(1) of the Convention, it is always necessary to choose the alternative that is most favourable to the protection of the rights enshrined in said treaty, based on the principle of the rule most favourable to the human being.

The procedural choices the African Court makes in how it approaches its mandate to protect human rights on the continent are going to be the most important decision it makes. The importance of this choice, under the circumstances I have set out in this article, is reinforced by the ambivalence the African Commission has expressed in its role to promote and uphold gay and lesbian rights and the potential impact this can have on its role as a conduit to the Court. The success in challenging these discriminatory laws at the Court centres largely on, firstly, reaching the Court and, secondly, persuading the Court to align itself with its regional counterparts. Article 31 of the Vienna Convention on the Law of Treaties promotes a purposive interpretation of any treaty, including the African Charter and the Protocol. The question that remains unanswered is whether the majority of the African Commission and Court would be willing to use the constructive avenues available if they were presented with an opportunity to do so, and whether they would draw on the positive work of their regional counterparts.

120 Atala (n 31 above) paras $83 \& 84$. 